\title{
ELECTROOPTICAL AND NONLINEAR OPTICAL PROPERTIES OF LYOTROPIC LIQUID CRYSTALS DOPED WITH ELECTROCHROMIC VIOLOGENS
}

\author{
H.B. BORDYUH, ${ }^{1}$ G.V. KLIMUSHEVA, ${ }^{2}$ A.P. POLISHCHUK ${ }^{1}$ \\ ${ }^{1}$ National Aviation University \\ (1, Prosp. Komarova, Kyiv 03058, Ukraine; e-mail: ghoul13@ukr. net) \\ ${ }^{2}$ Institute of Physics \\ (46, Prosp. Nauky, Kyiv 03680, Ukraine)
}

\begin{abstract}
This work presents the results of experimental studies of the electrooptical and nonlinear optical properties of lyotropic ionic liquid crystals (LILC) with soluted electrochromic admixtures of viologens. It is established that the Smectic A ordering of the LILC of potassium caprylate is not disrupted by the introduction of viologens. Moreover, LILC-viologen composites obtain electrochromic properties inherent to viologens, which produce colored radical cations and dimers, while reducing. The presence of radical cations and dimers is fixed by the optical absorption spectra. It is found that, under the action of an electric field, the LILC-viologen samples form a bilayer structure consisting of a liquid crystal layer and an absorptive layer of viologen redox products (radical cations and dimers). A dynamic grating recording is realized and studied in bilayer LILC-viologen cells. It is determined that the recording takes place in the colored layer of viologen redox products. A possible mechanism of grating recording in LILC-viologen cells is proposed.
\end{abstract}

\section{Introduction}

Up to now, the nonlinear optics of liquid crystals (LC) remains quite an underinvestigated area. The discovery of such properties in liquid crystals and their thorough studying lead to new nontraditional applications of LC materials. In works [1-3], it was shown that a good nonlinearity with fast response times was observed for lyotropic LC on the base of metal-alkanoates doped with various dyes and photosensitive admixtures and for thermotropic LC of cobalt alkanoates.

Among the above-mentioned materials, it is worth to note lyotropic ionic liquid crystals (LILC) doped with viologens, which are known due to their electrochromism. Electrochromic properties of viologens appear also in lyotropic LC media, making those materials promising for the further practical application.

In the present article, we give the detailed overview of electrooptical and nonlinear optical properties of the LILC-viologen complex materials and consider a possible mechanism of optical nonlinearity in such systems.

\section{Experimental Methods and Materials}

Electrochromic admixtures are represented by two compounds of the viologen class with the common chemical formula:

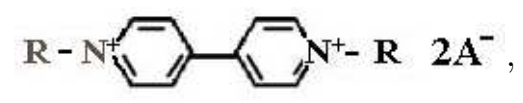

where $\mathbf{R}$ is a substitute, and $\mathbf{A}$ is a counterion.

For the first viologen (N,N'-diheptyl-4,4'-dipyridylium dibromide $-\mathrm{HD}^{2+} 2 \mathrm{Br}^{-}$), $\mathrm{R}=\mathrm{C}_{7} \mathrm{H}_{15}, \mathrm{~A}^{-}=\mathrm{Br}^{-}$; for the second one (N,N'-di(2-carboxyethyl)-4,4'-dipyridylium dichloride $\left.-\mathrm{CED}^{2+} \mathrm{Cl}^{-}\right) \mathrm{R}=\left(\mathrm{CH}_{2}\right)_{2} \mathrm{COOH}, \mathrm{A}^{-}=\mathrm{Cl}^{-}$.

Viologens are well soluble in water; therefore, they are also soluble in a lyotropic LC matrix. The lyotropic ionic liquid crystal on the base of potassium caprylate is formed under the mixing with water in the 1:1proportion. Its chemical formula is $\mathrm{C}_{7} \mathrm{H}_{15} \mathrm{COOK}: \mathrm{H}_{2} \mathrm{O}$. For preparing the samples, a powder of potassium caprylate was mixed with viologens ( $2 \%$ by weight) and then with water.

The obtained LILC-viologen system is characterized by the bilayer Smectic A ordering, which is not disrupted by the introduction of viologens [4]. Viologen molecules are harmonically built into the LILC matrix, so that their long-chained substitutes are situated along alkyl chains of potassium caprylate. Dipyridylium viologen rings are located in the electrostatic interlayer formed by potassium cations, water, and negatively charged oxygen atoms (Fig. 1). X-ray data for crystalline viologens [5] showed that the dipyridylium part of a viologen molecule has a size proportional to that of the electrostatic interlayer in LILC. Arranging the viologen molecules in such a way, the LILC matrix facilitates their transfer along electrostatic layers under the application of an electric field.

For the electrooptical and nonlinear optical investigations of the LILC-viologen samples, we used sand- 


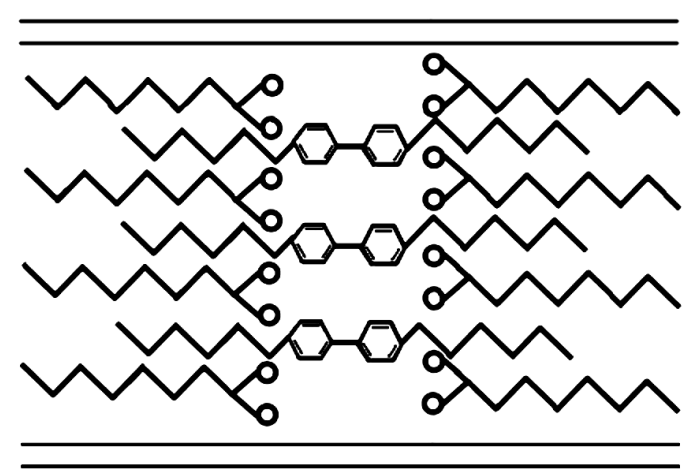

Fig. 1. Schematic representation of an LILC-viologen cell

wich cells, whose inner surface was covered with ITOelectrodes. The thickness of the samples varied from 15 to $20 \mu \mathrm{m}$ by teflon gaskets. Upon the observation with an optical polarization microscope, the LILC-viologen samples have the domain structure with planar orientation in each domain.

The visible absorption spectra of the LILC-viologen samples exposed to the action of a constant electric field were obtained with a spectrometer based on a monochromator MDR-6.

The investigation of nonlinear optical properties of the LILC-viologen samples and the measurement of their main holographic characteristics were carried out with the use of the methods of dynamic holography and nonlinear transmission measurement. The two-beam scheme was applied for the dynamic grating recording and the study of the corresponding diffraction efficiency. We used the second harmonic radiation of a pulse Qswitched Nd:YAP laser $\left(\mathrm{TEM}_{00}\right.$-mode, wavelength $\lambda=$ $539.8 \mathrm{~nm}$, pulse duration $\tau=20 \mathrm{~ns}$, frequency of pulses $\nu=3 \mathrm{~Hz}$ ). For the investigation of the relaxation kinetics of gratings, the recorded gratings were read by a testing nonpolarized radiation of a continuous $\mathrm{He}-\mathrm{Ne}$ laser (power $P=2 \mathrm{~mW}, \lambda=630 \mathrm{~nm}$ ).

\section{Results and Discussion}

\subsection{Electrooptical characteristics}

LILC of potassium caprylate does not absorb in the visible and near-ultraviolet regions. Viologens in the initial colorless state absorb only in the short-wave spectral region at a wavelength of $265 \mathrm{~nm}$. The injection of violo-

\begin{tabular}{l|l}
\hline $\mathrm{RV}^{2+}+\mathrm{e}^{-} \leftrightarrow \mathrm{RV}^{+}$ & Radical cation formation \\
$\mathrm{RV}^{+}+\mathrm{e}^{-} \leftrightarrow \mathrm{RV}^{0}$ & Biradical formation \\
$\mathrm{RV}^{2+}+\mathrm{RV}^{0} \leftrightarrow\left(\mathrm{RV}^{+}\right)_{2}$ & Dimer formation \\
\hline
\end{tabular}

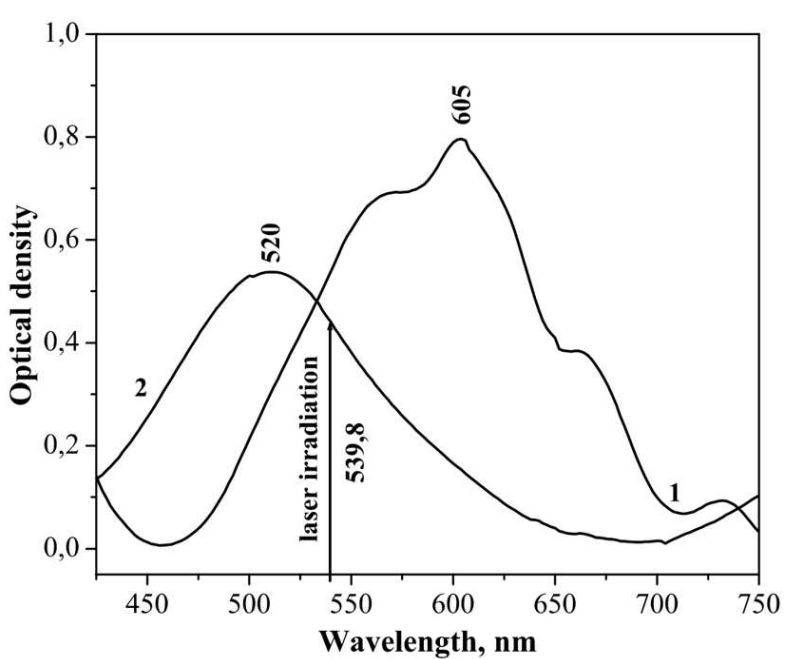

Fig. 2. Absorption spectrum of LILC- $\mathrm{HB}^{2+} 2 \mathrm{Br}^{-}$under the action of the electric field. Curve 1 corresponds to the generation of radical cations at the voltage $U=2.5 \mathrm{~V}$, curve 2 represents the formation of dimers at $U=4 \mathrm{~V}$. The cell thickness $w=20 \mu \mathrm{m}$

gens into the lyotropic liquid crystal medium practically does not influence the position of this band [6].

Under applying the electric field, a positively charged dipyridylium dication of viologens reduces in two steps with the following formation of colored redox products. At the first stage, a viologen molecule captures one electron producing a blue-colored radical cation. At the second stage, the radical cation catches one more electron and transforms into a biradical. Biradicals could turn into neutral molecules [7] or interact with initial viologen molecules coming up from the volume of the sample. This interaction leads to the formation of dimers and even larger associates, which are characterized by the red coloring [8].

For viologens introduced into the LILC matrix, we also observe the formation of radical cations and dimers. In the case of the LILC- $\mathrm{HD}^{2+} 2 \mathrm{Br}^{-}$system, the generation of radical cations occurs at the voltage $U=2.5 \mathrm{~V}$. In the optical spectrum of a sample, the corresponding wide absorption band has a maximum of the optical density at $\lambda=605 \mathrm{~nm}$ (Fig. 2, curve 1). The two-electron reduction takes place at the voltage $U=3 \mathrm{~V}$ causing the decoloration of the sample. The formation of dimers is observed after increasing the voltage up to $U=4 \mathrm{~V}$. The absorption band of dimers has a maximum at the wavelength $\lambda=520 \mathrm{~nm}$ (Fig. 2, curve 2).

The redox processes of the viologen $\mathrm{HD}^{2+} 2 \mathrm{Br}^{-}$in the LILC matrix are well resolved and prove the suggestion about the formation of dimers as a result of the interaction between biradicals and initial viologen molecules 


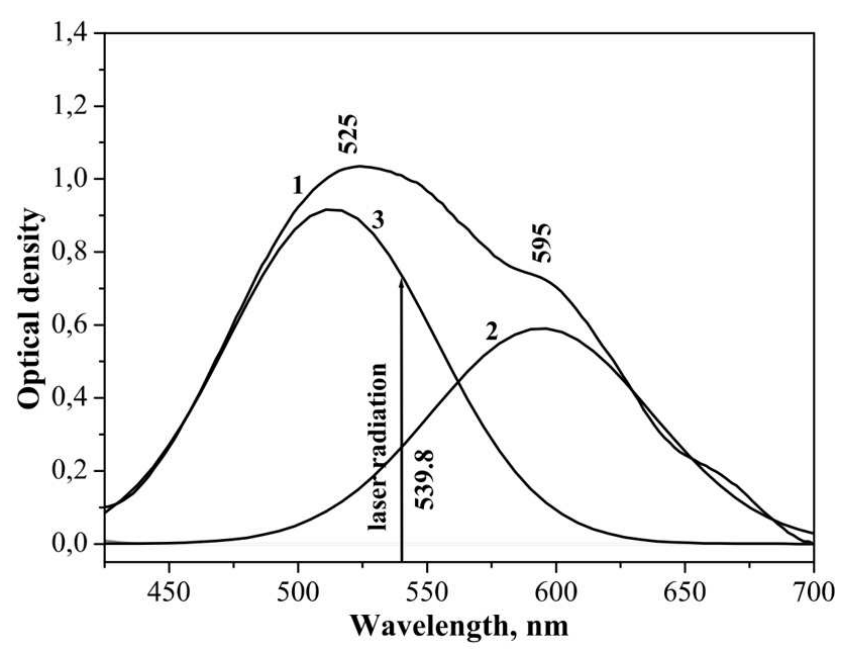

Fig. 3. Absorption spectrum of LILC-CEB ${ }^{2+} 2 \mathrm{Cl}^{-}$under the action of the electric field. Curve 1 corresponds to the generation of radical cations and dimers at the voltage $U=3 \mathrm{~V}$; curves 2 and 3 representing the absorption of radical cations and dimers are obtained as a result of the Gaussian factorizing. Cell thickness $w=20 \mu \mathrm{m}$

[8]. The interaction between radical cations with the following association into dimers [9] is impossible because of the observed decoloration of LILC-viologen cells at $U=3 \mathrm{~V}$. This means that the further dimerization processes begin when there are no radical cations in the sample.

Moreover, our suggestions concerning the dimerization are proved by quantum theory [10]. The absorption band of dimers is shifted to the violet region relative to the absorption band of radical cations. This means that, during the formation of dimers, molecules are situated in parallel to one another. In this case, the excitation transition between molecules allocated in antiparallel is forbidden, which makes it impossible for two radical cations to form a dimer.

In the case of LILC-CED ${ }^{2+} 2 \mathrm{Cl}^{-}$, the generation of radical cations and dimers occurs simultaneously at $U=$ $3 \mathrm{~V}$. A wide band with two maxima $(\lambda=525 \mathrm{~nm}$ and $\lambda=595 \mathrm{~nm})$ appears in the sample's absorption spectrum (Fig. 3, curve 1). Factorizing the spectrum into components by Gaussians, it is possible to distinguish two separate absorption bands, which obviously belong to radical cations and dimers (Fig. 3, curves 2 and 3). In the samples containing $\mathrm{CED}^{2+} 2 \mathrm{Cl}^{-}$, the redox reactions are running too rapidly to resolve them. This coincides with the data on the volt-ampere characteristics of the sample, in which two redox maxima merged into one [1]. Possibly, it is caused by the presence of functional carboxyl $\mathrm{COOH}$-groups in $\mathrm{CED}^{2+} 2 \mathrm{Cl}^{-}$viologen molecules.

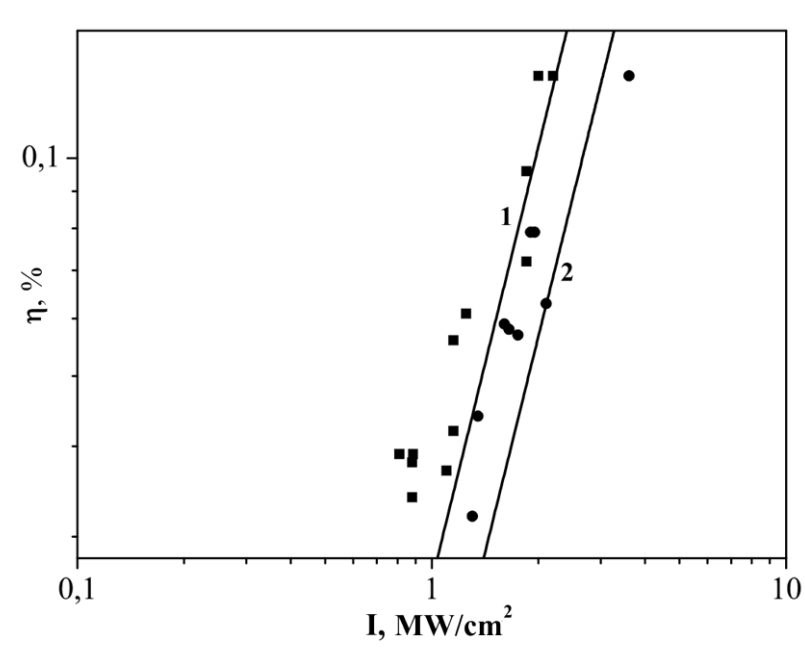

Fig. 4. Diffraction efficiency logarithm versus the laser radiation intensity for the colored samples of LILC-HB ${ }^{2+} 2 \mathrm{Br}^{-}(1)$ and LILC-CEB ${ }^{2+}{ }_{2} \mathrm{Cl}^{-}$(2). Dots represent experimental results, strait lines are obtained by calculations according to the mechanism of photoconversion. The grating period $\Lambda=20 \mu \mathrm{m}$, the optical density $D=0.46$, the cell thickness $w=20 \mu \mathrm{m}$

In both cases, the reduction and, therefore, coloration reactions are reversible. The lifetime of the colored state varies from seconds to hours and even more, by depending on the time and the applied voltage. These facts make LILC-viologen samples perspective for a practical usage.

It is established that, under the action of an electric field, the bilayer cell consisting of a liquid crystal layer and an absorptive layer of viologen redox products is formed in the samples of LILC-viologen. The maximum thickness of a viologen layer was estimated to be close to $d=400 \mathrm{~nm}$. The presence of a dichroism for colored LILC-viologen samples indicates the ordering of admixture molecules.

\subsection{Nonlinear optical characteristics}

It was found that LILC-viologen systems exert nonlinear optical properties. The diffraction grating recording passing in the self-diffraction regime was observed in the colored samples of LILC-HD ${ }^{2+} 2 \mathrm{Br}^{-}$and LILC$\mathrm{CED}^{2+} 2 \mathrm{Cl}^{-}$. It was determined that the recording takes place in the colored layer of viologen redox products. The value of the Cook-Klein parameter $(Q<0.1)$ corresponds to a thin grating recording.

The diffraction efficiency measured in the selfdiffraction regime depends in the second order on the intensity of a recording laser beam and has a linear dependence on the logarithmic scale (Fig. 4). Such a de- 


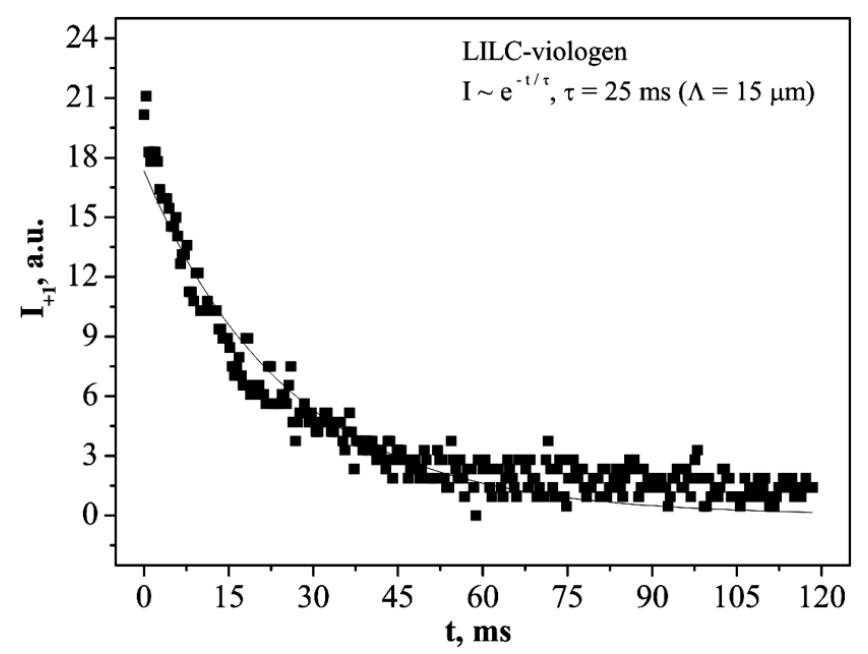

Fig. 5. Kinetics of gratings erasing in a microsecond region for the LILC-viologen samples. The relaxation constant $\tau=25 \mu$ s for the grating period $\Lambda=15 \mu \mathrm{m}$

pendence points at a cubic optical nonlinearity of the investigated samples.

The optical density of the LILC-viologens samples practically does not depend on the beam intensity, i.e., there is no nonlinear absorption in the given intensity range. The recorded gratings have a phase character.

The decay kinetics of residual gratings (Fig. 5) is typical of thermal gratings. But their diffraction efficiency is $1.5-2$ times less than that in the self-diffraction regime. So, the contribution of a thermal nonlinearity to the diffraction efficiency of the samples is insignificant.

Possible mechanisms of the optical nonlinearity in the LILC-viologen samples could be concerned with the effect of nonlinear polarization of the delocalized $\pi$ electrons of dipyridylium [11] and with the conversions of photosensitive viologen molecules caused by the action of a laser radiation. The last mechanism implies the reversible photoconversion of dimers into radical cations under the action of a laser pulse. Theoretical calculations performed according to this mechanism were presented in works $[1,12]$ and then specified.

The optical spectra of colored LILC-viologen samples show that the electronic states of singlet-singlet transitions of dimers and radical cations are disposed very closely. The laser radiation wavelength lies in the absorption region of both dimers and radical cations (Figs. 2 and 3). Therefore, a laser pulse excites both of them. Excited particles return to their ground states due to nonradiative transitions. At the same time, the transitions between the excited electronic states of dimers

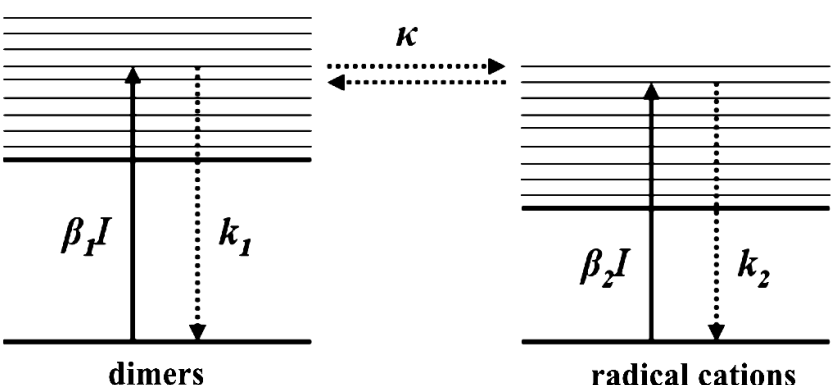

Fig. 6. Scheme of the energy levels of dimers and radical cations including the possible transitions under the laser excitation. $k_{1}=$ $k_{2}$ are the rates of nonradiative transitions between excited and ground states; $\kappa$ is the probability of the photoconversion; $I$ is the laser radiation intensity; $\beta_{i}=A_{i} \sigma_{i} / h \nu$, where $A_{i}$ is the quantum yield, $\sigma_{i}$ is the absorption cross-section

and radical cations could take place (Fig. 6). Thus, one dimer transforms into two radical cations.

A diffraction grating is recorded as a result of the difference in linear polarizabilities of dimers and radical cations, as well as of a change in the number of particles due to the photoconversion.

The solution of the standard system of kinetic equations written according to the photoconversion mechanism $[1,12]$ gives a change of the number of dimers and radical cations in the excited and ground states under a laser pulse. Knowing the number of particles, it is possible to calculate a refractive index modulation, which appears to have a linear character in the operating intensity range [1]:

$\Delta n=\frac{2 \pi}{n_{0}}\left(\alpha_{d} N_{d}^{*}+\alpha_{r} N_{r}^{*}\right)$,

where $\alpha_{d}$ and $\alpha_{r}$ are, respectively, the polarizabilities of dimers and radical cations; $N_{d}^{*}$ and $N_{r}^{*}$ are the numbers of excited dimers and radical cations; $n_{0}=1.44$ is the mean refractive index. The inclination angle of the $\Delta n$ dependence gives us a possibility to calculate the effective third-order dielectric susceptibility $\chi^{(3)}$ of the colored viologen derivatives. The estimated susceptibilities reach the high values of $\chi^{(3)}=5.4 \times 10^{-7} \mathrm{esu}$ for LILC- $\mathrm{HD}^{2+} 2 \mathrm{Br}^{-}$and $\chi^{(3)}=4.3 \times 10^{-7}$ esu for LILC$\mathrm{CED}^{2+} 2 \mathrm{Cl}^{-}$. According to the literature data $[13,14]$, the close values are peculiar to some organics in the case when the exciting laser radiation wavelength coincides with their absorption band.

The value of diffraction efficiency could be calculated by using the following formula for a thin phase grating [15]:

$\eta=\frac{I_{1}}{I_{0}}=T\left(\pi \Delta n \frac{d}{\lambda}\right)^{2}$ 
Here, $I_{1}$ is the intensity in the first diffraction order, $I_{0}$ is the input beam intensity; $T$ is the transmission, $d$ is the thickness of an absorptive layer, and $\lambda$ is the laser radiation wavelength.

The results of calculations of the diffraction efficiency according to the photoconversion mechanism fit well the experimental results (Fig. 4). Consequently, the mechanism of reversible photoconversion could describe the optical nonlinearity in LILC-viologen samples.

\section{Conclusions}

1. It is established that the smectic-ordered LILCviologen composites obtain electrochromic properties inherent to viologens, which produce colored radical cations and dimers, while reducing. The values of applied voltage needed for the generation of radical cations and dimers are determined.

2. The presence of radical cations and dimers is fixed by optical absorption spectra. Thus, the radical cations are characterized by the absorption band with $\lambda=605$ $\mathrm{nm}$. The absorption band at $\lambda=520 \mathrm{~nm}$ corresponds to the dimerization of viologens. It is found that, under the action of an electric field, the samples of LILC-viologen form a bilayer structure consisting of a liquid crystal layer and an absorptive layer of viologen redox products (radical cations and dimers).

3. It is clarified that the LILC-viologen samples obtain a cubic optical nonlinearity. The recordered gratings appear to be thin and phase ones. The possible mechanism of the LILC-viologen optical nonlinearity could be the reversible photoconversion of dimers into radical cations under the action of a laser pulse.

1. A.B. Bordyuh, Yu.A. Garbovskiy, S.A. Bugaychuk, G.V. Klimusheva, T.A. Mirnaya, G.G. Yaremchuk, and A.P. Polishchuk, Opt. Mat. 31, 1109 (2009).

2. G. Klimusheva, S. Bugaychuk, Yu. Garbovskiy, O. Kolesnik, T. Mirnaya, and A. Ishchenko, Opt. Lett. 31, 235 (2006).

3. Yu.A. Garbovskiy, A.V. Gridyakina, G.V. Klimusheva, A.S. Tolochko, I.I Tokmenko, and T.A. Mirnaya, Liq. Cryst. 37, 1411 (2010).

4. A.B. Bordyuh, A.P. Polishchuk, G.V. Klimusheva, A.S. Tolochko, T.A. Mirnaya, and G.G. Yaremchuk, Rus. Journ. Phys. Chem. 79, 866 (2005).

5. A.B. Bordyuh, A.P. Polishchuk, I.Yu. Polishchuk, G.V. Klimusheva, A.V. Gridyakina, L.G. Grineva, Kristallogr. 50, 460 (2005).

6. A.B. Bordyuh, A.P. Polishchuk, I.Yu. Polishchuk, G.V. Klimusheva, T.A. Mirnaya, G.G. Yaremchuk, and O.V. Koval'chuk, Ukr. J. Phys. 49, 1098 (2004).
7. V.N. Gratchev, S.I. Zhdanov, and G.S. Supin, Electrochem. XIV, 1353 (1978).

8. P.M.S. Monk, R.D. Fairweather, M.D. Ingram, and J.A. Duffy, J. Electroanal. Chem. 359, 301 (1993).

9. E.M. Kosower and J.L. Cotter, J. Amer. Chem. Soc. 86, 5524 (1964).

10. M. Pope, Electronic Processes in Organic Crystals (Oxford Univ. Press, Oxford, 1982).

11. A.B. Bordyuh, Yu.A. Garbovskiy, G.V. Klimusheva, S.A. Bugaychuk, T.A. Mirnaya, G.G. Yaremchuk, and A.P. Polishchuk, Ukr. J. Phys. 53, 1167 (2008).

12. A. Bordyuh, Yu. Garbovskiy, S. Bugaychuk, G. Klimusheva, and V. Reshetnyak, Mol. Cryst. Liq. Cryst. 508, 296 (2009).

13. S. Tatsuura, O. Wada, M. Tian, M. Furuki, Y. Sato, I. Iwasa, L. Sun Pu, and H. Kawashima, Appl. Phys. Lett. 79, 2517 (2001).

14. G. Fu, T. Yoda, K. Kasatani, H. Okamoto, and Sh. Takenaka, Synt. Met. 155, 68 (2005).

15. H.J. Eichler, P.G. Gunter, and D.W. Pohl, Laser-Induced Dynamic Gratings (Springer, Berlin, 1986).

Received 22.09.11

ЕЛЕКТРООПТИЧНІ ТА НЕЛІНІЙНО-ОПТИЧНІ ВЛАСТИВОСТІ ЛІОТРОПНИХ РІДКИХ КРИСТАЛІВ, ДОПОВАНИХ ЕЛЕКТРОХРОМНИМИ ВІОЛОГЕНАМИ

\section{А.Б. Бордюг, Г.В. Клімушева, А.П. Поліщук}

Р е $з$ ю м е

У цій роботі наведено результати експериментальних досліджень електрооптичних та нелінійно-оптичних властивостей ліотропних іонних рідких кристалів (ЛІРК) з розчиненими в них електрохромними домішками віологенів. Було з'ясовано, що смектичне А впорядкування ЛIPК на основі каприлату калію не порушується при внесенні віологенів. Більше того, композити ЛІРК-віологен проявляють електрохромні властивості, що є характерними для віологенів, які здатні при відновленні генерувати забарвлені катіон-радикали та димери. Наявність у зразках катіон-радикалів і димерів підтверджується оптичними спектрами поглинання. Було визначено, що під дією електричного поля зразки ЛІРК-віологен утворюють двошарову структуру, що складається із шару рідкого кристала та поглинаючого шару продуктів відновлення віологенів (катіонрадикалів та димерів). У таких двошарових комірках здійснено динамічний запис дифракційних граток. Було з'ясовано, що запис відбувається у забарвленому шарі продуктів відновлення віологенів. Відповідно до отриманих нелінійно-оптичних характеристик зразків ЛІРК-віологен запропоновано можливий механізм оптичної нелінійності у них. 